\title{
The Dark Side of the Economy: A Comparative Analysis of the Islamic State's Revenue Streams
}

\section{by Wes H Cooper}

\section{(cc) $\mathrm{BY}$}

This work is licensed under a Creative Commons Attribution 3.0 License.

\begin{abstract}
The Islamic State's ambitious goals have led to the organization obtaining a large amount of costs. However, the Islamic State does not have adequate revenue streams to maintain these expenditures. This paper compares the Islamic State's costs and revenue streams with two similar organizations, Hizballah and Al Qaeda. The comparison will explain that the Islamic State's revenue streams are not as efficient and diversified as Hizballah and Al Qaeda's revenue streams have historically been. As a result of inefficient and unvaried revenue streams, the Islamic State will be forced to structurally change.
\end{abstract}

Keywords: Islamic State; ISIS; terrorism; crime; Al Qaeda; Hizballah; terrorist financing

\section{Economic Inefficiencies of the Islamic State}

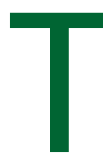

his paper will explain that the Islamic State (IS) will not be able to sustain itself with its current revenue streams by comparing IS' costs and revenue streams to other similar organizations. The first part of the paper will provide a brief overview of the expenditures of terrorist organizations. The second part will examine al-Qaeda, Hizballah, and IS' expenses and sources of funding. The third part will explain the problems in IS' revenue streams. The paper will conclude by describing how finances may force IS to change as an organization.

Organizations that conduct terror operations must fund several overheads, including the living costs of the organization's members, reliable communication channels, training for new recruits, travel expenses, propaganda (Gomez, 2010), military activities, religious institutions, social services, and charities (Rudner, 2010). Although organizations that conduct terror operations have similar costs, these are not exactly the same. IS actually has more costs than other terrorist organizations, over $\$ 5$ million USD per month. This is because IS incurs state-like costs such as administering territory and paying civilian and law enforcement personnel (Zelin, 2015).

Terrorist organizations finance themselves in a variety of ways, including the sale of oil, extortion, human trafficking, arms trafficking, drug trafficking, money laundering, hawala (an informal system of moving cash), kidnapping ransoms, and offshore companies (Gomez, 2010). A single terrorist organization may not use all of these methods of funding. For example, IS mostly uses local sources of funding (United States Department of Treasury, 2014), including taxes and local criminal activities (ibid). As a result, IS does not gain much funds from global activities, such as global trafficking, off-shore banking, and money laundering. In fact, previous research has shown that IS' current integration in the international financial system is inefficient. Two other organizations similar to IS have been more involved in global financing activities: Hizballah and Al Qaeda. 


\section{Overview of Organizations}

\section{Al-Qaeda and its Affiliates}

Osama Bin Laden founded Al Qaeda (AQ) in 1988 with three primary goals: to rid Muslim areas of western influence, to drive out the governments of Islamic countries that did not follow Osama Bin Laden's interpretation of sharia law, and to establish a caliphate. After the September 2001 attacks, the US and UK launched a military operation that caused AQ members to flee from Afghanistan to Pakistan. This resulted in AQ transforming from an organization with a strict military hierarchy to an organization with a loose skeleton structure. Later, in 2011 Osama Bin Laden was killed by US Navy Seals in Pakistan after which Ayman al-Zawahiri began to lead AQ. Since Osama Bin Laden's death, AQ has been challenged by AQ's off shoot organization, IS (National Consortium for the Study of Terrorism and Responses to Terrorism, 2015).

Before the September 2001 attacks, a CIA report estimated that AQ required around US \$30 million annually (Gomez, 2010). This money was used for several activities, including carrying out terrorist attacks, training members, and for donations to associated organizations and the Taliban. Due to AQ's restructuring, it is difficult to know the organization's current costs. However, estimates of the costs of the organization's terrorist attacks since 2001 total over US \$500,000. In addition to terrorist attacks, AQ must fund several other activities, including salaries of members, communication equipment, training members, travel costs, propaganda, and charitable activities (ibid). The funds to finance these activities come from several sources, including oil (Warde, 2007), donors, trafficking (human trafficking and drug trafficking), money laundering, hawala, kidnapping for ransom, and offshore companies (Gomez, 2010).

AQ has received donations from a range of different donors, including charities and people in the Gulf region. AQ has also diverted funds from legitimate charitable organizations to AQ's illicit activities and has created fake charity organizations to obtain funds. With regard to drug trafficking, the Spanish police found that drug trafficking groups active in the North African enclaves gave a percentage of their profits to AQ. AQ has also used financial companies to fund itself. Barakaat is one such organization. Barakaat was a network of companies that performed various services, including telecommunications, construction, and cash exchange services. The company's owners transferred millions of dollars from the US to AQ and its associates. Al Qaeda in the Islamic Maghreb (AQIM) also used inactive companies and liquidating companies in the Bahamas and Delaware to receive funds (Gomez, 2010). Hawala, a supposedly paperless financial system that is based on trust (Geode, 2003), has also been used by AQ to receive financing (Gomez, 2010). Additionally, AQ has received money from the sale of oil. It is estimated that the organization received billions of dollars from the sale of oil between 2000 and 2003 (Warde, 2007).

\section{Hizballah}

Hizballah formed in 1982 when independent Shiite militant groups united to fight off the Israeli invasion of Lebanon. The organization has undergone several transformations over the years, including a change in goals. When first created, Hizballah's main goal was to remove foreign forces from Lebanon. However, due to the signature of the Taif Agreement of 1989 and Israel's removal of troops from Lebanon in 2000, this is no longer a goal of Hizballah. Currently, Hizballah's main goals are to spread Shiite Islam, destroy Israel, and provide liberation and freedom to Palestinians (National Consortium for the Study of Terrorism and Responses to Terrorism, 2015). 


\section{Journal of Terrorism Research}

Hizballah has several expenses, including wages, communication costs, military activities and equipment, propaganda activities, religious institutions, social services and charities, and training members. It is estimated that it costs Hizballah approximately US \$500 million per year to fund these expenditures. The organization uses several sources of funding, including state sponsors, commercial profits, donations and charitable contributions, and a variety of criminal activities (Rudner, 2010).

A considerable amount of Hizballah's funding comes from the Iranian government. It is estimated that the Iranian government provides the organization with around $\$ 100$ to $\$ 200$ million annually (ibid). Iran has been able to donate so much money because of the significant income Iran makes from oil sales (Schott, n.d.). Allegedly, Hizballah also uses the organizations Bayt al-Mal and the Yousser Company to manage assets and mediate with the formal banking system. Bayt al-Mal is reportedly used for investing, banking, and crediting. Bayt al-Mal uses the Yousser Company to secure loans and make business deals that support Hizballah's operations. Much like AQ, Hizballah also uses hawala to finance operations. The organization has also diverted donations from legitimate charities to fund Hizballah's activities. Additionally, Hizballah has gained profits from charitable front organizations, such as Bonyad-e Shahid (the Martyrs Foundation). In 2002, A branch of Bonyad-e Shahid was shut down in Germany. It is believed that the Paraguayan branch of Bonyad-e Shahid sent at least \$50 million USD to Hezbollah (Levitt, 2005). The German organization, the al-Shahid Social Relief Institution, was also found to be raising money for Hizballah. Criminal activities Hizballah has used to obtain funding include human, drugs, and arms trafficking, and fraud. It has also been reported that Hizballah has performed these activities in North America. For example, Canadian reports have documented Hizballah's role in the theft and re-export of automobiles and financial fraud in Canada (Rudner, 2010). It is estimated that Hizballah and other Middle Eastern terrorist groups receive around US \$20 to US \$30 million from fraudulent activities in North America. Hizbullah also receives around US \$10 million from illicit activities in South America (Levitt, 2005).

\section{The Islamic State}

The Islamic State (IS) first started as an affiliate of al-Qaeda when Abu Musab al-Zarqawi's organization, Jama'at al Twawhid w'al-Jihad, became an affiliate of al-Qaeda. At this time IS was known as al-Qaeda in Iraq (AQI). Zarqawi was later killed in a US air strike (Laub \& Masters, 2016), which led to Abu Omar Baghdadi becoming the new leader of AQI. During Omar Baghdadi's tenure as leader, he changed AQI's name to the Islamic State of Iraq (ISI). Later, Omar Baghdadi and Au Ayyub al Masri, another ISI leader, were killed in a US air strike. After these two leaders were killed, Abu Bakr al Baghdadi was declared the new leader. Under Bakr al Baghdadi's leadership, ISI set its eyes on expanding into Syria. ISI later expanded into Syria and changed its name to the Islamic State of Iraq and Syria/Sham (ISIS). The following year, the organization announced that the Caliphate had been re-established and changed its name once again. This time the name was changed to the Islamic State (IS) (Barrett, 2014).

Leaked documents reveal that IS' costs are higher than other groups at US $\$ 5,587,000$, for just the month of March 2014. If expenditures were similar for other months in the year of 2014 then IS expenditures totaled around US $\$ 67,044,000$ for the year of 2014 (Zelin, 2015). IS’ costs include wages for its members, communication, training, travel, propaganda, and military activities (United States Department of Treasury, 2014). Total accounting income for the organization was recorded at $\$ 8,438,000$ USD for the month of March 2014. The leaked document cited oil wells ( $27.7 \%$ of income), electricity (3.9\% of income), taxes ( $23.7 \%$ of income), and confiscations (47.7\% of income) as revenue streams (Zelin, 2015). Most of IS' income is illegal, 


\section{Journal of Terrorism Research}

including kidnapping, selling oil and ancient artifacts on the black market, extortion, and other criminal activities (United States Department of Treasury, 2014). These illegal activities are likely to be categorized under oil wells, taxes and confiscations (Zelin, 2015).

IS sells its oil at substantially discounted prices (Woertz, 2014). There is evidence that oil from IS controlled areas has been sold to Kurds who then resell the oil to Turkey. Additionally, the Syrian government has made an agreement with IS to purchase oil. Estimates say that IS receives US \$1 million per day from selling oil. However, IS' oil industry has suffered from airstrikes (ibid). Increased security at the borders of Turkey and Kurdistan have also lowered IS' oil revenue, but IS has still been able to obtain a large amount of revenue from oil sales (United States Department of Treasury, 2014).

Kidnapping also generates millions of dollars for IS. The organization kidnaps individuals and offers to release them for large ransoms. If the ransom is not paid, then IS threatens to kill the individual. In the spring of 2014, IS released hostages after receiving payments from several European states. It is estimated that in one year, IS received US \$20 million to US \$45 million from kidnappings (FATF Report, 2015). IS also gains funds from kidnapping and trafficking people from the Yezidi minority group, which make up the majority of people in IS' human trafficking ring. Yezidi women and girls are sold, forcibly married, or given as gifts (Amnesty International, 2014).

US \$200 million of IS' funds are estimated to be attributed to cultural looting (Singer 2015), likely categorized under taxes in the organization's accounting system (Zelin, 2015). Cultural looting involves stealing valuables from museums and ancient sites. IS encourages people in IS controlled areas to pillage archaeological sites by issuing them permits. Once permit holders in IS controlled areas obtain artifacts, IS takes a percentage of the revenue permit holders receive from selling artifacts (Singer, 2015).

IS also profits from a variety of other criminal activities, including robbing banks, stealing livestock and crops, and extortion. In fact, several accounts have risen of IS extorting money from Iraqis. The organization has also demanded a percentage of money from cash bank withdrawals and has targeted minorities with increased amounts of extortion (United States Department of Treasury, 2014). Additionally, IS has received funds from several donors. However, by mid-2014, donations were no longer a significant percentage of IS' revenue (Barrett, 2014).

\section{Inefficiency in the Islamic State}

IS, Hizballah, and AQ are all very similar organizations. All three organizations have extreme political goals, work toward obtaining goals through terrorist activities, and fund their organizations through the use of criminal and terrorist activities. However, IS is the only organization that has been quickly carrying out an ambitious goal to establish a state (Institute for the Study of War, n.d.). This ambition has increased IS' expenditures. While IS has more expenditures than Hizballah and AQ, IS also has several problems in its revenue streams.

The oil fields IS uses to raise revenue suffer from several problems. For example, oil fields in Syria are mature and need water injection to maintain production (Woertz, 2014). Water injection involves the disposing of water produced by exploited oil reservoirs. This must be done because, as exploited oil reservoirs mature, more water is produced in place of oil which makes the oil fields inefficient. This water injection process can be complex (International Association of Oil and Gas Producers, 2000) and requires considerable expertise. Syria's rate of oil production has also been falling. The last year Syria's oil fields operated normally, in 2011, oil 
production was at 327,000 bpd. Since the unrest in Syria, oil production fell to 56,000 bpd in 2013 (Woertz, 2014).

Iraq has more lucrative oil fields, but most of these oil fields are out of IS' control. Iraq also has energy problems of its own. For example, Iraq does not have much capacity for domestic refining and power generation and much of Iraq's natural gas is being flared. Additionally, the price for which IS sells oil must be competitive against competing oil producers. As a result, a decrease in world gas prices could lead to IS receiving less profit from the sale of oil. Also, the amount of money IS currently receives from oil may be a substantial amount of money for a terrorist organization, but it is a small amount of money for an organization, such as IS, with state-like costs (ibid).

In comparison to IS, both AQ and Hizballah have more complex revenue streams than IS. This is largely due to AQ and Hizballah's deeper involvement in the international financial system. For example, AQ and Hizballah have both used front companies and charities to generate revenue. These two organizations have also engaged in international criminal activities, including financial fraud (Rudner, 2010) and international drug trafficking (Gomez, 2010). While AQ and Hizballah have more complex revenue streams than IS, both organizations are not acquiring and maintaining territory. Instead of ruling territory like IS, AQ and Hizballah function within states. As a result, AQ and Hizballah do not have to finance state-like overheads.

Unlike AQ and Hizballah, IS is not heavily involved in the international financial system. Most of IS's funds come from local criminal and terrorist activities (United States Department of Treasury, 2014). This dependence on local criminal and terrorist activities means the organization must maintain the revenue it receives from these activities. However, local criminal and terrorist activities are declining revenue streams. In other words, the value of these revenue streams will decline as IS continues to use them. For example, IS will not be able to continue selling artifacts because there is a finite amount of archaeological sites in Iraq and Syria. As IS excavates more archaeological sites, the amount of income that could potentially be generated from this activity will decrease.

Additionally, if IS continues to steal from local areas, then the organization will start to run out of goods to steal. The only way for IS to continue to get revenue from these activities would be to expand its territory. However, expansion could be a big problem for IS because as the organization expands its costs will increase. With expansion, the organization will have to maintain and protect more territory and will have to pay for more members. Even if IS expanded and obtained more revenue from local criminal and terrorist activities, the increase in revenue may not be enough to cover increased costs.

Previous research also shows that the funds IS receives from all other resources of its territory, including the taxation on trade and services, does not efficiently offset the cost of running a state, in the long run. This is because IS' taxation mechanism will likely create a decline in aggregate demand and could potentially hurt the labor market and the ability of people to save parts of their income. For example, the tax that IS places on Iraqi and Syrian government workers living in IS controlled areas reduces incentives for citizens to spend cash and interact with IS' financial system (Hansen-Lewis \& Shapiro, 2015). Additionally, IS' taxes on education, fuel and vehicles, and bank cash withdrawals are regressive. This regressive tax policy leads to people with less money having to pay more taxes. Since lower income people have to spend such a large amount of money paying taxes they have less discretionary income. As a result, there are less incentives for saving money (ibid), seeing as money must be spent on necessities (Burman, 2012). IS' other taxes could potentially lead to barriers in the growth of businesses, since their inconsistent imposition can create uncertainties in IS' regulatory environment. IS also runs into the problem of having to leave citizens with 
surplus income to invest in future production, which is essential to growing the economy of a new state. This problem is based on historical evidence that extractive states-states that receive a significant amount of funds from natural resources (Oxford Dictionaries, n.d.)-lasted a long time when they left their citizens with enough production surplus to invest in future production. In other words, for IS to continue as an extractive state, the organization must leave people under their control with more income. In order for IS to do this the organization needs to reduce taxes. However, this reduction in taxes would cause a loss in revenue. If IS decided to promote economic growth and reduce taxes, then the loss in tax revenue could be recouped by engaging further in the international financial system. Further engagement in the international system would also lead to people in IS occupied areas having more discretionary income and more incentives to buy goods. As a result, aggregate demand in the economy would increase and further economic growth would be created (Hansen-Lewis \& Shapiro, 2015).

\section{The Future of the Islamic State}

In light of IS' high costs, revenue problems and inefficiency, the organization will be forced to make one of six decisions. These decisions include increasing territory, decreasing territory, or maintaining current territorial size while either seeking more international and efficient revenue streams or while maintaining current revenue streams. These six decisions are based on past research that shows revenue generation is an important form of support for terrorist organizations (Brown, 2010). Figure 1 shows a list of the six decisions.

\begin{tabular}{|l|l|}
\hline $\begin{array}{l}\text { (1) Increasing territory while seeking more } \\
\text { international and efficient revenue streams }\end{array}$ & $\begin{array}{l}\text { (4) Increasing territory while maintaining } \\
\text { current revenue streams }\end{array}$ \\
\hline $\begin{array}{l}\text { (2) Decreasing territory while seeking more } \\
\text { international and efficient revenue streams }\end{array}$ & $\begin{array}{l}\text { (5) Decreasing territory while maintaining } \\
\text { current revenue streams }\end{array}$ \\
\hline $\begin{array}{l}\text { (3) Maintaining territorial size while seeking } \\
\text { more international and efficient revenue streams }\end{array}$ & $\begin{array}{l}\text { (6) Maintaining territorial size while } \\
\text { maintaining current revenue streams }\end{array}$ \\
\hline
\end{tabular}

Figure 1

Decision 1 would lead to IS having more total revenue. Under this decision, IS' revenue would equal current revenue streams and new more efficient revenue streams. Current revenue streams would include the inefficient revenue streams that IS currently uses. New revenue streams would include more engagement in international financial activities. Under decision 2, IS could run more efficiently depending on how much territory IS gives up and how integrated IS becomes in the international financial system. If IS decreases territory and increases international and efficient revenue streams to a level were revenue from these new revenue streams is greater than total costs, then IS would operate more efficiently in the long run.

The third decision would lead to the organization not being dependent on declining revenue streams and could lead to increased income. This is because maintaining current territory while gaining more efficient revenue streams would cause IS' revenue to equal current revenue and new more efficient revenue streams. As a result, in the long run, IS would have more discretionary income that could potentially be used for terrorist activity.

Decision 4 could lead to IS collapsing as a state entity since decision 4 involves only increasing inefficient territorial holding revenue sources. The outcomes of decision 5 depends on how much territory IS gives up, as giving up too much territory would cause IS to lose a lot of income from its territorial holding revenue 


\section{Journal of Terrorism Research}

streams and giving up a smaller amount of territory would not cause as much of a decrease in revenue. Since decision 6 involves maintaining current declining revenue streams and not seeking out other revenue streams, the organization could cease to exist as a state entity if IS follows decision 6.

It would be in the US' and other states' best interest if IS weakened from overextending itself or collapsed from a decline in revenue. These scenarios are most likely to happen under decision 4 and decision 6 . Since decision 4 entails increasing in territorial size but not seeking out efficient and international revenue streams, IS would continue to be dependent on inefficient revenue streams. As a result, decision 4 would lead to IS not being able to cover costs in the long run. This inability to cover expenses while striving to gain new territory would cause IS to continue to lose territory. In other words, the organization would be spreading itself too thin. Decision 6, which involves keeping revenue sources and territorial holdings at their current values, would lead to IS experiencing a decline in revenue in the long run due to the inefficiency in IS' revenue streams.

If IS actually weakened from overextending itself or collapsed from a decline in revenue, then it will likely result in IS trying to become a non-territory holding actor. The reason for this is it would be easier to find funds to cover the costs of funding a terrorist attack than funding a state since it is cheaper to fund terrorist attacks (Zelin, 2015). This shift to becoming a non-territorial holding terrorist organization like AQ could be highly problematic if it were not for the fact that IS relies on declining revenue streams from local areas. In order for IS to be a long lasting and formidable non-state actor, IS would have to become more engaged in the international financial system. This means that IS would likely be a weaker organization if it became a non-territory holding actor, assuming that it does not become further integrated in the international financial system. On the other hand, if IS is able to further engage in the international financial system while becoming a non-territory holding actor, it may become a stronger organization that is capable of carrying out more expensive terrorist operations. This would be the worst case scenario. It is important to remember that these decisions and scenarios are ceteris paribus. They do not take into account changes, such as increased military intervention in IS controlled areas. If military intervention in IS controlled areas is increased, then this could create a bigger burden on IS' costs and the organization as a whole.

\section{About the author}

Wes Cooper obtained a bachelor of science in Sociology and Anthropology with a minor in international studies from Towson University. While studying at Towson University, he also worked as a copy editor for the Towson University Journal of International Affairs. He is currently working toward his master of arts in Global Affairs and Human Security at the University of Baltimore. His research interests include global crime, terrorism, and global economics. Wes Cooper is particularly interested in the social and cultural phenomena that influence global crime and terrorism and how terrorism is financed. Wes Cooper has also published research about terrorism and the formation of the Islamic State of Iraq and Syria.

\section{Bibliography}

Amnesty International. Escape from Hell- Torture, Sexual Slavery in Islamic State Captivity in Iraq. Report. December 22, 2014. Accessed April 10, 2016. http://www.cidob.org/en/publications/publication_series/ notes_internacionals/n1_98/how_long_will_isis_last_economically\#.

Barrett, Richard. “The Islamic State.” The Soufan Group, November 2014. Accessed April 10, 2016. http:// 
soufangroup.com/wp-content/uploads/2014/10/TSG-The-Islamic-State-Nov14.pdf.

Brown, Michael E. Contending with Terrorism: Roots, Strategies, and Responses. Cambridge, MA: MIT Press, 2010.

Burman, Len. “A Progressive Consumption Tax?” Forbes. June 4, 2012. Accessed November 29, 2016. http:// www.forbes.com/sites/leonardburman/2012/06/04/a-progressive-consumption-tax/\#73ca958316d4.

FATF Report. "Financing of the Terrorist Organisation Islamic State in Iraq and the Levant (ISIL)." FATF, February 2015. http://www.fatf-gafi.org/media/fatf/documents/reports/Financing-of-the-terroristorganisation-ISIL.pdf.

Goede, Marieke De. "Hawala Discourses and the War on Terrorist Finance." Environ Plan D Environment and Planning D: Society and Space 21, no. 5 (2003): 513-32. doi:10.1068/d310t.

Gómez, Juan Miguel Del Cid. "A Financial Profile of the Terrorism of Al-Qaeda and Its Affiliates." Perspectives on Terrorism 4 (2010). Accessed April 10, 2016. http://www.terrorismanalysts.com/pt/index. $\mathrm{php} / \mathrm{pot} /$ article/view/113/html.

Hansen-Lewis, Jamie, and Jacob N. Shapiro. "Understanding the Daesh Economy." Perspectives on Terrorism 9, no. 4 (2015). Accessed November 29, 2016. http://terrorismanalysts.com/pt/index.php/pot/issue/view/53.

Institute for the Study of War. "The Islamic State: A Counter-Strategy for a Counter-State." Institute for the Study of War. Accessed April 10, 2016. http://www.understandingwar.org/report/islamic-state-counterstrategy-counter-state.

International Association of Oil and Gas Producers. Guidelines for Produced Water Injection. Report no. 2.80/302. January 2000. Accessed April 10, 2016. http://www.ogp.org.uk/pubs/302.pdf.

Laub, Zachary, and Jonathan Masters. "The Islamic State." Council on Foreign Relations. March 22, 2016. Accessed April 10, 2016. http://www.cfr.org/iraq/islamic-state/p14811.

Levitt, Matthew. "Hezbollah Finances: Funding the Party of God." Hezbollah Finances: Funding the Party of God The Washington Institute for Near East Policy. February 2005. Accessed December 01, 2016. http:// www.washingtoninstitute.org/policy-analysis/view/hezbollah-finances-funding-the-party-of-god.

National Consortium for the Study of Terrorism and Responses to Terrorism. "Al-Qa'ida." March 2015. Accessed April 10, 2016. http://www.start.umd.edu/baad/narratives/al-qaida\#_edn3.

Oxford Dictionaries. “Oxford Dictionaries Dictionary, Thesaurus, \& Grammar." Oxford Dictionaries. Accessed December 02, 2016. https://en.oxforddictionaries.com/.

Rudner, Martin. "Hizbullah Terrorism Finance: Fund-Raising and Money-Laundering." Studies in Conflict \& Terrorism 33, no. 8 (2010): 700-15. Accessed April 10, 2016. doi:10.1080/1057610x.2010.494169.

Schott, Jeffrey J. Economic Sanctions, Oil, and Iran. Report. Accessed April 10, 2016. http://www.iranwatch. org/sites/default/files/us-congress-jec-schott-iran-energy-072506.pdf.

Singer, Graciela Gestoso. “ISIS' War on Cultural Heritage and Memory." Centro De Estudios De Historia Del Antiguo Oriente (CEHAO) Pontifical Catholic University of Argentina, May 9, 2015. Accessed April 10, 2016. doi:10.1017/cbo9781107444911.

United States Department of Treasury. "Remarks of Under Secretary for Terrorism and Financial Intelligence David S. Cohen at the Carnegie Endowment for International Peace, “Attacking ISIL's Financial Foundation'”' News release, October 23, 2014. U.S. Department of the Treasury. Accessed April 10, 2016. https://www. 


\section{Journal of Terrorism Research}

treasury.gov/press-center/press-releases/Pages/j12672.aspx.

Warde, Ibrahim. The Price of Fear: Al-Qaeda and the Truth behind the Financial War on Terror. London: I.B. Tauris, 2007.

Woertz, Eckart. “How Long Will ISIS Last Economically?” Notes Internationals CIDOB, October 2014. Accessed April 10, 2016. http://www.cidob.org/en/publications/publication_series/notes_internacionals/ n1_98/how_long_will_isis_last_economically\#.

Zelin, Aaron Y. “The Archivist: Unseen Islamic State Financial Accounts for Deir Az-Zor Province.” JIHADOLOGY: A Clearinghouse for Jihādī Primary Source Material, Original Analysis, and Translation Service. October 04, 2015. Accessed December 01, 2016. http://jihadology.net/2015/10/05/the-archivistunseen-islamic-state-financial-accounts-for-deir-az-zor-province/. 